\title{
Correction to: Deploying new generation sequencing for the study of flesh color depletion in Atlantic Salmon (Salmo salar)
}

Thu Thi Minh Vo ${ }^{1,2,3}$, Tuan Viet Nguyen ${ }^{4}$, Gianluca Amoroso ${ }^{5}$, Tomer Ventura ${ }^{1,2^{*}}$ and Abigail Elizur ${ }^{1 *}$

Correction to: BMC Genomics 22, 545 (2021)

https://doi.org/10.1186/s12864-021-07884-9

Following publication of the original article [1], it was reported that an incorrect image was published as Fig.6. The correct Fig. 6 is included in this Correction and the original article has been corrected.

The original article can be found online at https://doi.org/10.1186/s12864021-07884-9.

*Correspondence: tventura@usc.edu.au; aelizur@usc.edu.au

${ }^{1}$ GeneCology Research Centre, University of the Sunshine Coast, Sunshine Coast, Queensland, Australia

Full list of author information is available at the end of the article

(c) The Author(s). 2021 Open Access This article is licensed under a Creative Commons Attribution 4.0 International License, which permits use, sharing, adaptation, distribution and reproduction in any medium or format, as long as you give appropriate credit to the original author(s) and the source, provide a link to the Creative Commons licence, and indicate if changes were made. The images or other third party material in this article are included in the article's Creative Commons licence, unless indicated otherwise in a credit line to the material. If material is not included in the article's Creative Commons licence and your intended use is not permitted by statutory regulation or exceeds the permitted use, you will need to obtain permission directly from the copyright holder. To view a copy of this licence, visit http://creativecommons.org/licenses/by/4.0/. The Creative Commons Public Domain Dedication waiver (http://creativecommons.org/publicdomain/zero/1.0/) applies to the data made available in this article, unless otherwise stated in a credit line to the data. 


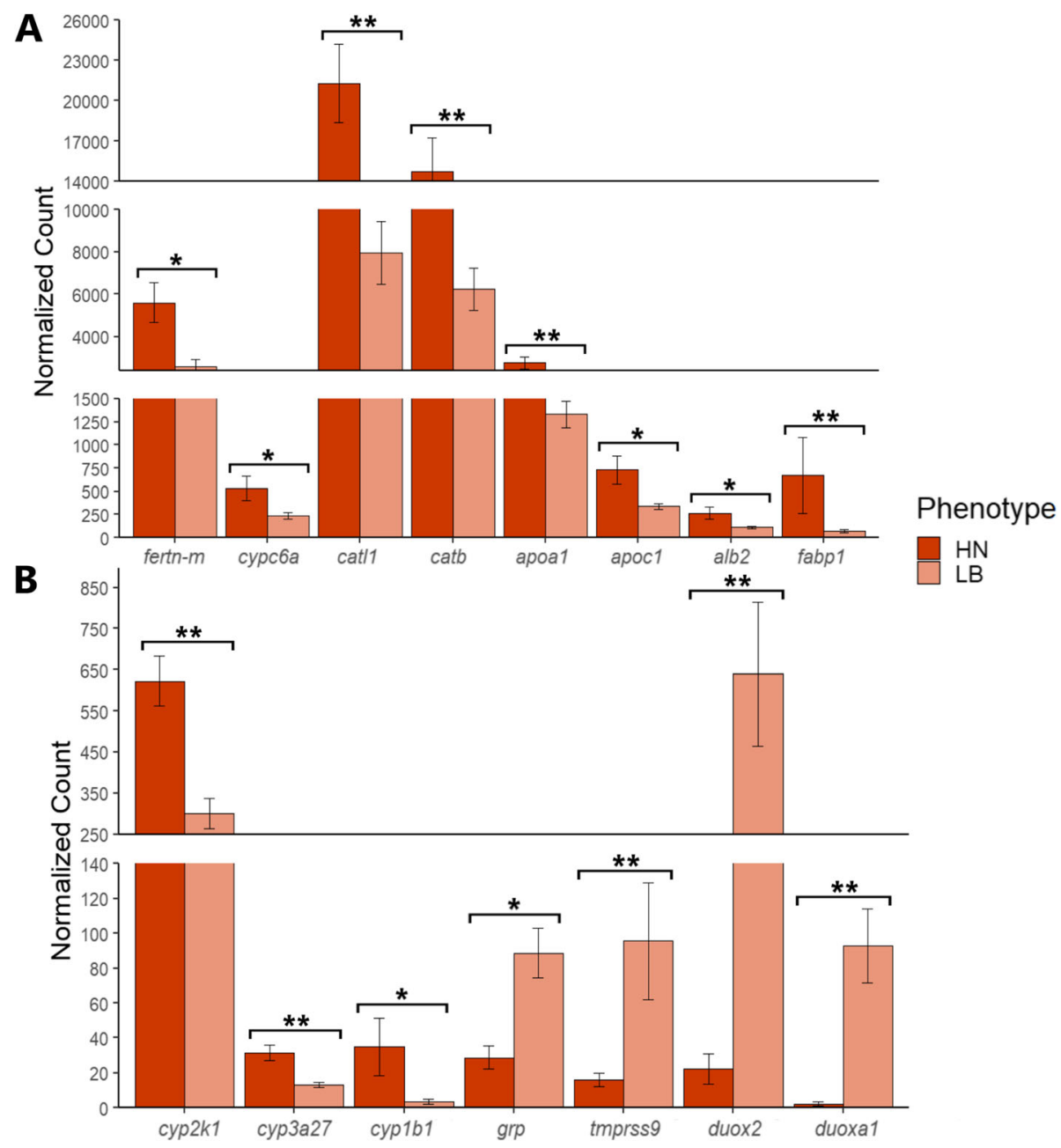

Fig. 6 Analysis comparing HN and LB phenotypes. Subset of DEGs of interest identified in the transcriptiomes from the two library preprations. A Expression pattern of eight genes identified in the QuantSeq library: ferritin-m (fertn-m), involved in iron ion transport; cytochrome c oxidative subunit 6 A mitochondrial-like (cypc6a), involved in oxidation-reduction process; cathepsin L1 (catl1) and cathepsin B (catb) involved in apoptosis and muscle degradation; apolipoprotein A1 (apoa1), apolipoprotein C1 (apoc1), serum albumin 2 (alb2), fatty acid-binding protein 1 (fabp1) involved in lipid metabolism; B Expression pattern of seven genes identified in the TruSeq library: cyp450 gene family cyp2k1, cyp3a27 and cyp1b1, involved in oxidation-reduction process; gastrin-releasing peptide (grp) involved in regulation of feeding, and tmprss9, dual oxidase 2-like (duox2), dual oxidase maturation factor 1-like (duoxa1) involved in SNP analysis. Asterisks (* and ${ }^{*}$ ) indicate significant difference between the HN and LB phenotypes at $P<0.05$ and $P<0.01$, respectively

\section{Author details}

${ }^{1}$ GeneCology Research Centre, University of the Sunshine Coast, Sunshine Coast, Queensland, Australia. ${ }^{2}$ School of Science, Technology and Engineering, University of the Sunshine Coast, Sunshine Coast, Queensland, Australia. ${ }^{3}$ School of Biotechnology, International University, Viet Nam National University, Ho Chi Minh 700000, Vietnam. ${ }^{4}$ Centre for AgriBiosciences, AgriBio, Agriculture Victoria, Bundoora, Victoria 3083, Australia. ${ }^{5}$ Petuna Aquaculture, East Devonport, Tasmania 7310, Australia.

Published online: 30 September 2021

\section{Reference}

1. Vo TTM, Nguyen TV, Amoroso G, Ventura T, Elizur A. Deploying new generation sequencing for the study of flesh color depletion in Atlantic Salmon (Salmo salar). BMC Genomics. 2021;22(1):545. https://doi.org/10.11 86/s1 2864-021-07884-9. 